\title{
English as Medium of Instruction at Primary Level: Problems Faced by Teachers and
}

\author{
Students \\ * Mushtaq Ahmad Tanoli, PhD Scholar \\ ** Muhammad Ilyas Khan, Associate Professor \\ *** Muhammad Iqbal Majoka, Professor (Corresponding Author)
}

\begin{abstract}
This study was conducted to investigate problems faced by teachers and students in the teachinglearning process using English as the medium of instruction at the primary level. The study explored the teachers' competencies and students' abilities needed regarding the use of English as a medium of instruction. A survey research design was used to conduct the study. A questionnaire was administered to a sample of 380 randomly selected teachers of 350 primary schools of HazaraChiSquare Chi Square Goodness of Fit Test was used for the data analysis. Findings revealed that most primary school teachers found it difficult to teach different subjects using English as medium of instruction. Teachers did not seem to be able to provide a suitable learning environment for students in the EMI context. In comparison to students who did not seem to face substantial issues in understanding their lessons through EMI, teachers faced more difficulties in the effective use of EMI for their teaching. This could be linked to their lack of teachers' training for an EMI teaching environment. The study has important implications as the medium of instruction conundrum does not seem to go away in the Pakistani school education context in general and at the primary level of education in particular.
\end{abstract}

Keywords: EMI, Primary School Teachers, Primary School Students, Problems Faced in

\section{Introduction}

Medium of instruction is an important consideration in educational contexts (Wolff, 2006). Defining English medium of instruction (EMI) is a difficult undertaking as the re are overlapping domains of English for Academic Purposes (EAP), English as Foreign Language (EFL), Teaching of English as Foreign Language (TEFL), Teaching of English as Second Language (TESL), English for Specific Purposes (ESP) and Content and Language Integrated Learning (CLIL). One definition of EMI revolves around the use of the English language for teaching all the academic subjects in non-English countries. A recent report published jointly by the British Council and EMI Oxford points out that EMI is rapidly expanding across the globe. The report says that instead of being taught as a foreign language in education English is increasingly being used now as a medium of instruction (Dearden, 2016).

In Pakistan, English language learning is also a popular demand because this language is instrumental in providing extensive job prospects. The national education policies and the governments in the provinces of Punjab and Khyber Pakhtunkhwa, Pakistan have been making efforts to implement the policy of adopting English medium instruction at the elementary school level (Bari, 2014). Each decision followed a comprehensive program ranging from writing the textbooks to teacher training. As part of those initiatives, thousands of teachers and hundreds of master trainers have been inducted for teacher training. Most of these policies were well received at the public level (Buneri, 2014).

There has been a substantial amount of politics surrounding language and medium of instruction polic ies in Pakistan (Shamim, 2008). The Education Policy of 2009 also proposed to use the English language for teaching science and mathematics from grade four onwards but, as Coleman (2010) points out, the policy is not clear and there are several contradictions in the policy documents.

* Department of Education, Hazara University Mansehra

** Department of Education, Hazara University Mansehra

*** Department of Education, Hazara University Mansehra 
One of the most important issues standing in the way of useful execution of EMI at the school level has been the lack of skilled and competent teachers. There is a general lack of qualified and competent primary school teachers for EMI. In 2015 the British Council assessed 2008 primary school teachers through the British Council's Apt is language testing system and found out their general lack of basic working English (Dearden, 2016). This, however, may not be generalized to all areas of the country as there are variations at different levels of education, localities, schools, teachers, and students (Keuk \& Tith, 2013).

The presentation so far indicates that there is scope for this important issue to be explored further on an empirical basis in the Pakistani context. The real stakeholders, that is, teachers and students, and their views, needs, and problems need to be investigated for the introduction of EMI through a top-down approach (Macaro, 2018).

\section{Objectives of the Study}

This study had the following objectives:

1. To explore the competencies the primary school teachers require for teaching through EMI at the primary level.

2. To investigate problems students and teachers face in the use of EMI at the primary level.

\section{Review of Related Literature}

Studies indicate the medium of instruction has been a longstanding issue in the Pakistani context (Mustafa, 2011; Rassool \& Mansoor, 2007; Mansoor, 2004; Rahman, 1996). There has been a good deal of debate regarding the merits and demerits of EMI in the Pakistani context. Some oppose the use of EMI in schools based on its failure in the process of real learning and because of certain ideological positioning. The White Paper on Education (2006) opposed the adoption of EMI at the primary level. Those opposing EMI argue that this stands in the way of real learning on the part of students (Mustafa, 2013 \& 2020). Besides, Dearden (2015) argues that more than EMI the educational infrastructure in most of the countries is a hurdle in the way of effective EMI provision and the lack of trained teachers and scarcity of clear guidelines are some of the issues that affect EMI. She points out that the failure of EMI should not be associated with student learning as its success depends on several other factors.

Skeptics also argue that EMI is not generally helpful either in content learning or in English language profic iency (Lei \& $\mathrm{Hu}, 2014$ ). However, despite the increased interest in EMI at the primary level there seems to be a lack of an appropriate pedagogical and theoretical framework for teaching through the medium of English (Kim, 2011). Other researchers argue that the problem is with the teachers and the methodology of EMI implementation (Manan \& Dumanig, 2015). After successive attempts of adopting EMI policy in the government schools in Pakistan, the reports of its failure also started to appear. One of these studies found out the effects and issues of English medium instruction on students at schools. Quantitative data were collected from 85 teachers of 17 different schools and it was concluded that the introduction of EMI for teaching science and mathematics was not useful because only a limited number of students understood lessons (Saeed, Iqbal, \& Azam, 2012).

Another study conducted by the Society for Advancement of Education (SAHE) in the government schools in the province of Punjab to evaluate the effects of English Medium Instruction on the students produced similar results as it was found out that school teachers were not skillful to teach Maths and Science lessons using EMI. More than 50 percent of teachers did not endorse the policy of EMI. It was suggested that English medium instruction would not improve learning and teaching without competent teachers. It was suggested that instead of making English a medium of instruction, it should be taught effectively as a subject at the primary level (Rashid, Muzaffar, Butt, Awan, \& Bashiruddin, 2013).

There is thus a good deal of debate surrounding the use of EMI in the Pakistani educational context. The present study is focused on the problems teachers and students faced in teaching and learning through the medium of English. The paper explores the problems associated with its successful implementation at the primary level. As Shamim (2008) says there is a need to assess the effects of EMI on the students because only a limited number of empirical studies are available in Pakistan about the EMI impact on students' learning.

\section{Method}

This study adopted a quantitative, survey research design. Ponto (2015) describes survey research as, gathering information from a sample of individuals through questionnaires. Survey research designs 
are useful for quantitative, large-scale studies (Singleton \& Straits, 2009). In the present study, a survey was used to collect information in the light of objectives of the study.

\section{Population}

The population of this study consisted of 15640 primary school teachers serving in 6221 public sector primary schools in the target area of six districts of Hazara division from the Khyber Pakhtunkhwa province of Pakistan.

\section{Sample}

A simple random sampling method (as suggested by Gravetter \& Forzana, 2009) was used to choose a sample of schools for this study. The number of primary school teachers selected as the sample of the study was 380 from 350 primary schools located at fourteen Tehsils of six districts in Hazara Division. The size is sufficient for the generalization of research findings with a $95 \%$ level of confidence.

\section{Validity \& Reliability}

Validity and reliability were ensured using strategies including 1) A well-constructed and comprehensive survey instrument was used that was peer-reviewed using face and content validity techniques; 2) To improve the overall validity and reliability of the study the appropriate sample was used (Cohen et al., 2007); 3) For the improvement of internal validity of the study suitable data analys is framework was used. Cronbach's alpha coefficient was calculated for checking the reliability of the research instrument, and its value of found to be 0.892 .

\section{Data Analysis and Interpre tation}

Table 1

Teachers ' perceptions about their EMI competency

\begin{tabular}{|c|c|c|c|c|c|c|c|c|}
\hline \multirow{2}{*}{$\begin{array}{l}\mathrm{Sr} \\
\text { No. }\end{array}$} & \multirow{2}{*}{ Statement } & \multicolumn{5}{|c|}{ Observed Frequency } & \multirow{2}{*}{$x^{2}$} & \multirow{2}{*}{$\mathrm{p}$} \\
\hline & & SA & A & UD & DA & SDA & & \\
\hline 1 & $\begin{array}{l}\text { The students are provided a } 100 \% \\
\text { EMI environment by me }\end{array}$ & $\begin{array}{l}9 \\
(2 \%)\end{array}$ & $\begin{array}{l}42 \\
(11 \%)\end{array}$ & $\begin{array}{l}21 \\
(6 \%)\end{array}$ & $\begin{array}{l}162 \\
(43 \%)\end{array}$ & $\begin{array}{l}146 \\
(38 \%)\end{array}$ & 275.9 & 0.000 \\
\hline 2 & $\begin{array}{l}\text { No problem is encountered by me in } \\
\text { understanding the subject content } \\
\text { for teaching }\end{array}$ & $\begin{array}{l}11 \\
(3 \%)\end{array}$ & $\begin{array}{l}111 \\
(29 \%)\end{array}$ & $\begin{array}{l}7 \\
(2 \%)\end{array}$ & $\begin{array}{l}150 \\
(40 \%)\end{array}$ & $\begin{array}{l}101 \\
(27 \%)\end{array}$ & 214.6 & 0.000 \\
\hline 3 & $\begin{array}{l}\text { No problems are met in teaching all } \\
\text { the subjects through EMI by me }\end{array}$ & $\begin{array}{l}9 \\
(3 \%)\end{array}$ & $\begin{array}{l}68 \\
(18 \%)\end{array}$ & $\begin{array}{l}7 \\
(2 \%)\end{array}$ & $\begin{array}{l}123 \\
(32 \%)\end{array}$ & $\begin{array}{l}173 \\
(46 \%)\end{array}$ & 275.4 & 0.000 \\
\hline 4 & $\begin{array}{l}\text { Examining students through EMI is } \\
\text { easy for me }\end{array}$ & $\begin{array}{l}13 \\
(3 \%)\end{array}$ & $\begin{array}{l}67 \\
(18 \%)\end{array}$ & $\begin{array}{l}11 \\
(3 \%)\end{array}$ & $\begin{array}{l}148 \\
(39 \%)\end{array}$ & $\begin{array}{l}141 \\
(37 \%)\end{array}$ & 232.7 & 0.000 \\
\hline 5 & $\begin{array}{l}\text { I can explain a concept with } \\
\text { different examples in English when } \\
\text { teaching through EMI }\end{array}$ & $\begin{array}{l}3 \\
(1 \%)\end{array}$ & $\begin{array}{l}72 \\
(19 \%)\end{array}$ & $\begin{array}{l}8 \\
(2 \%)\end{array}$ & $\begin{array}{l}144 \\
(38 \%)\end{array}$ & $\begin{array}{l}153 \\
(40 \%)\end{array}$ & 270.0 & 0.000 \\
\hline 6 & $\begin{array}{l}\text { When explained in English my } \\
\text { students understand easily }\end{array}$ & $\begin{array}{l}7 \\
(2 \%)\end{array}$ & $\begin{array}{l}71 \\
(19 \%)\end{array}$ & $\begin{array}{l}7 \\
(2 \%)\end{array}$ & $\begin{array}{l}137 \\
(36 \%)\end{array}$ & $\begin{array}{l}158 \\
(42 \%)\end{array}$ & 261.1 & 0.000 \\
\hline 7 & $\begin{array}{l}\text { Through EMI, I can simplify the } \\
\text { difficult concepts for my students }\end{array}$ & $\begin{array}{l}7 \\
(2 \%)\end{array}$ & $\begin{array}{l}68 \\
(18 \%)\end{array}$ & $\begin{array}{l}6 \\
(2 \%)\end{array}$ & $\begin{array}{l}141 \\
(37 \%)\end{array}$ & $\begin{array}{l}158 \\
(42 \%)\end{array}$ & 274.6 & 0.000 \\
\hline 8 & $\begin{array}{l}\text { I can speak grammatically correct } \\
\text { English fluently with correct } \\
\text { pronunciation and intonation }\end{array}$ & $\begin{array}{l}6 \\
(2 \%)\end{array}$ & $\begin{array}{l}34 \\
(9 \%)\end{array}$ & $\begin{array}{l}5 \\
(1 \%)\end{array}$ & $\begin{array}{l}164 \\
(43 \%)\end{array}$ & $\begin{array}{l}171 \\
(45 \%)\end{array}$ & 374.7 & 0.000 \\
\hline
\end{tabular}

$\mathrm{df}=4 \quad$ Expected Frequency-76

Statistical analys is of statement No.1 reveals a significant $(\Upsilon 2=275.9, \mathrm{p}<0.05)$ disagreement $(\mathrm{DA}=43 \%, \mathrm{SDA}=38 \%)$ of the respondents about the provision of $100 \%$ EMI environment by them to their students.

Analyzed data regarding statement No. 2 indicate a significant $(\triangle 2=214.6$ and $\mathrm{p}<0.05)$ disagreement $(\mathrm{DA}=40 \%, \mathrm{SDA}=27 \%)$ of the respondents about the fact that they encountered no problem in understanding the subject contents for teaching. 
Statistical analysis of statement No. 3 reveals a significant $(\triangle 2=275.4$ and $p<0.05)$ disagreement $(\mathrm{DA}=32 \%, \mathrm{SDA}=46 \%)$ of respondents about the fact that no problems were faced by them in teaching all the subjects through EMI.

Analyzed data regarding statement No. 4 indicates a significant $(X 2=232.7$ and $p<0.05)$ disagreement $(\mathrm{DA}=39 \%, \mathrm{SDA}=37 \%)$ of the teachers about the fact that examining students through EMI was easy for them

Statistical analysis of statement No. 5 shows a significant $\left(\chi_{2}=232.7\right.$ and $\left.p<0.05\right)$ disagreement $(\mathrm{DA}=38 \%, \mathrm{SDA}=40 \%)$ of the respondents regarding the fact that they could explain a concept with different examples in English through EMI

Analyzed data regarding statement No.6 indicates significant $(X 2=261.1$ and $p<0.05)$ disagreement $(\mathrm{DA}=36 \%, \mathrm{SDA}=42 \%)$ of respondents about the fact that their explanation in the English language was understandable for the students while using EMI.

Statistical analysis of statement No. 7 indicates a significant $(X 2=274.6$ and $\mathrm{p}<0.05)$ disagreement $(\mathrm{DA}=37 \%, \mathrm{SDA}=42 \%$ ) of the respondents about the declaration that they could simplify the difficult concepts for their students while using EMI.

Analyzed data regarding statement No. 8 shows a significant $(\Upsilon 2=274.7$ and $p<0.05)$ disagreement $(\mathrm{DA}=43 \%, \mathrm{SDA}=45 \%)$ of the respondents about the declaration that they could speak grammatically correct English fluently with correct pronunciation and intonation.

Table 2

Teachers' perceptions about problems faced by students in the use of EMI

\begin{tabular}{|c|c|c|c|c|c|c|c|c|}
\hline \multirow{2}{*}{$\begin{array}{l}\mathrm{Sr} \\
\text { No. }\end{array}$} & \multirow{2}{*}{ Statement } & \multicolumn{5}{|c|}{ Observed Frequency } & \multirow{2}{*}{$x^{2}$} & \multirow{2}{*}{$\mathrm{P}$} \\
\hline & & SA & A & UD & DA & SDA & & \\
\hline 1 & $\begin{array}{l}\text { I provide intense exposure to the } \\
\text { English language to the students }\end{array}$ & $\begin{array}{l}5 \\
(1 \%)\end{array}$ & $\begin{array}{l}6 \\
(2 \%)\end{array}$ & $\begin{array}{l}5 \\
(1 \%)\end{array}$ & $\begin{array}{l}140 \\
(37 \%)\end{array}$ & $\begin{array}{l}224 \\
(59 \%)\end{array}$ & 539.2 & 0.000 \\
\hline 2 & $\begin{array}{l}\text { Language of instruction and daily } \\
\text { conversation is easily understood by } \\
\text { the students }\end{array}$ & $\begin{array}{l}128 \\
(34 \%)\end{array}$ & $\begin{array}{l}230 \\
(61 \%)\end{array}$ & $\begin{array}{l}6 \\
(2 \%)\end{array}$ & $\begin{array}{l}10 \\
(3 \%)\end{array}$ & $\begin{array}{l}6 \\
(2 \%)\end{array}$ & 533.9 & 0.000 \\
\hline 3 & $\begin{array}{l}\text { In English Medium schools, the } \\
\text { learning is enjoyable }\end{array}$ & $\begin{array}{l}148 \\
(39 \%)\end{array}$ & $\begin{array}{l}207 \\
(55 \%)\end{array}$ & $\begin{array}{l}9 \\
(2 \%)\end{array}$ & $\begin{array}{l}9 \\
(2 \%)\end{array}$ & $\begin{array}{l}7 \\
(2 \%)\end{array}$ & 474.8 & 0.000 \\
\hline 4 & $\begin{array}{l}\text { Children's learning gets supported } \\
\text { by parents in EMI }\end{array}$ & $\begin{array}{l}6 \\
(2 \%)\end{array}$ & $\begin{array}{l}5 \\
(1 \%)\end{array}$ & $\begin{array}{l}5 \\
(1 \%)\end{array}$ & $\begin{array}{l}131 \\
(35 \%)\end{array}$ & $\begin{array}{l}233 \\
(61 \%)\end{array}$ & 561.3 & 0.000 \\
\hline 5 & $\begin{array}{l}\text { New habits and techniques are } \\
\text { developed by students for learning } \\
\text { in an EMI setting }\end{array}$ & $\begin{array}{l}154 \\
(41 \%)\end{array}$ & $\begin{array}{l}208 \\
(55 \%)\end{array}$ & $\begin{array}{l}7 \\
(2 \%)\end{array}$ & $\begin{array}{l}6 \\
(2 \%)\end{array}$ & $\begin{array}{l}5 \\
(1 \%)\end{array}$ & 502.8 & 0.000 \\
\hline 6 & $\begin{array}{l}\text { EMI provides a welcoming } \\
\text { environment for the students }\end{array}$ & $\begin{array}{l}148 \\
(39 \%)\end{array}$ & $\begin{array}{l}209 \\
(55 \%)\end{array}$ & $\begin{array}{l}7 \\
(2 \%)\end{array}$ & $\begin{array}{l}9 \\
(2 \%)\end{array}$ & $\begin{array}{l}7 \\
(2 \%)\end{array}$ & 485.3 & 0.000 \\
\hline 7 & $\begin{array}{l}\text { In EMI schools the students' dropout } \\
\text { rate is high }\end{array}$ & $\begin{array}{l}5 \\
(1 \%)\end{array}$ & $\begin{array}{l}16 \\
(4 \%)\end{array}$ & $\begin{array}{l}6 \\
(2 \%)\end{array}$ & $\begin{array}{l}135 \\
(36 \%)\end{array}$ & $\begin{array}{l}218 \\
(57 \%)\end{array}$ & 489.3 & 0.000 \\
\hline 8 & $\begin{array}{l}\text { Students quickly adjust themselves } \\
\text { to EMI schools }\end{array}$ & $\begin{array}{l}215 \\
(57 \%)\end{array}$ & $\begin{array}{l}135 \\
(36 \%)\end{array}$ & $\begin{array}{l}7 \\
(2 \%)\end{array}$ & $\begin{array}{l}16 \\
(4 \%)\end{array}$ & $\begin{array}{l}7 \\
(2 \%)\end{array}$ & 472.7 & 0.000 \\
\hline 9 & $\begin{array}{l}\text { The introduction of EMI at the } \\
\text { primary level is beneficial for the } \\
\text { students }\end{array}$ & $\begin{array}{l}226 \\
(60 \%)\end{array}$ & $\begin{array}{l}137 \\
(36 \%)\end{array}$ & $\begin{array}{l}6 \\
(2 \%)\end{array}$ & $\begin{array}{l}6 \\
(2 \%)\end{array}$ & $\begin{array}{l}5 \\
(1 \%)\end{array}$ & 540.3 & 0.000 \\
\hline
\end{tabular}

$\mathrm{df}=4 \quad$ Expected Frequency-76

Statistical analys is regarding statement No. 1 indicates a significant $(\triangle 2=539.2$ and $p<0.05)$ disagreement ( $\mathrm{DA}=37 \%, \mathrm{SDA}=59 \%$ ) of the respondents about the assertion that they provided intense exposure of English language to the students

Analyzed data regarding statement No. 2 indicates a significant $(X 2=533.9$ and $\mathrm{p}<0.05)$ agreement $(A=61 \%, S A=34 \%)$ of the respondents about the claim that the language of instruction and the daily conversation was easily understood by their students. 
Analyzed data of the statement No. 3 indicates a significant $(\triangle 2=474.8$ and $\mathrm{p}<0.05)$ agreement $(\mathrm{A}=55 \%, \mathrm{SA}=39 \%)$ of the respondents regarding the claim that the learning process was enjoyable in English Medium schools.

Statistical analysis of statement No. 4 testifies that the respondents significantly $(X 2=561.3$ and $\mathrm{p}<0.05)$ disagreed $(\mathrm{DA}=35 \%, \mathrm{SDA}=61 \%)$ that the children's learning got supported by parents in EMI.

Statistical values regarding statement No.5 indicate a significant $(X 2=502.8$ and $\mathrm{p}<0.05)$ agreement $(\mathrm{A}=55 \%, \mathrm{SA}=41 \%)$ of the respondent about declaration that learning in EMI setting developed new habits and techniques among students.

Analyzed data regarding statement No. 6 shows a significant $\left(\Upsilon_{2}=485.3\right.$ and $\left.\mathrm{p}<0.05\right)$ agreement $(\mathrm{A}=55 \%, \mathrm{SA}=39 \%)$ of the respondents about the claim that EMI provided a welcoming environment for the students.

Analyzed data regarding statement No.7 indicates a significant $(X 2=489.3$ and $p<0.05)$ disagreement $(\mathrm{DA}=36 \%, \mathrm{SDA}=57 \%)$ of the respondents about the claim that students' dropout rate was high in the schools having EMI.

Analyzed data regarding statement No. 8 shows a significant $(\Upsilon 2=472.7$ and $p<0.05)$ agreement $(\mathrm{A}=36 \%, \mathrm{SA}=57 \%)$ of the respondents about the claim that the students quickly adjusted themselves in schools having EMI.

Analyzed data regarding statement No. 9 indicates a significant $(\Upsilon 2=540.3$ and $p<0.05)$ agreement $(\mathrm{A}=36 \%, \mathrm{SA}=60 \%)$ of the respondents about the claim that the introduction of EMI at the primary level was beneficial for the students.

The overall analyses of all statements indicate that students do not feel any substantial difficulty while learning through the medium of English language at the primary school level.

Table 3

Teachers' perceptions about the problems they face in the use of EMI

\begin{tabular}{|c|c|c|c|c|c|c|c|c|}
\hline \multirow{2}{*}{$\begin{array}{l}\mathrm{Sr} \\
\text { No. }\end{array}$} & \multirow{2}{*}{ Statement } & \multicolumn{5}{|c|}{ Observed Frequency } & \multirow{2}{*}{$x^{2}$} & \multirow{2}{*}{$\mathrm{p}$} \\
\hline & & SA & A & UD & DA & SDA & & \\
\hline 1 & $\begin{array}{l}\text { I provide a good model of English to } \\
\text { the students }\end{array}$ & $\begin{array}{l}9 \\
(2 \%)\end{array}$ & $\begin{array}{l}16 \\
(4 \%)\end{array}$ & $\begin{array}{l}21 \\
(6 \%)\end{array}$ & $\begin{array}{l}140 \\
37 \%)\end{array}$ & $\begin{array}{l}194 \\
(51 \%)\end{array}$ & 383.3 & 0.000 \\
\hline 2 & $\begin{array}{l}\text { I have received training for teaching } \\
\text { through EMI }\end{array}$ & $\begin{array}{l}8 \\
(2 \%)\end{array}$ & $\begin{array}{l}10 \\
(3 \%)\end{array}$ & $\begin{array}{l}7 \\
(2 \%)\end{array}$ & $\begin{array}{l}140 \\
(37 \%)\end{array}$ & $\begin{array}{l}215 \\
(57 \%)\end{array}$ & 488.9 & 0.000 \\
\hline 3 & $\begin{array}{l}\text { Teachers are provided enough } \\
\text { departmental opportunities to } \\
\text { improve their capacity for EMI }\end{array}$ & $\begin{array}{l}6 \\
(2 \%)\end{array}$ & $\begin{array}{l}6 \\
(2 \%)\end{array}$ & $\begin{array}{l}7 \\
(2 \%)\end{array}$ & $\begin{array}{l}130 \\
(34 \%)\end{array}$ & $\begin{array}{l}231 \\
(61 \%)\end{array}$ & 546.1 & 0.000 \\
\hline 4 & $\begin{array}{l}\text { EMI is is a part of pre-service and } \\
\text { in-service training. }\end{array}$ & $\begin{array}{l}6 \\
(2 \%)\end{array}$ & $\begin{array}{l}7 \\
(2 \%)\end{array}$ & $\begin{array}{l}6 \\
(2 \%)\end{array}$ & $\begin{array}{l}139 \\
(37 \%)\end{array}$ & $\begin{array}{l}222 \\
(58 \%)\end{array}$ & 524.3 & 0.000 \\
\hline 5 & The teachers can teach through EMI & $\begin{array}{l}7 \\
(2 \%)\end{array}$ & $\begin{array}{l}7 \\
(2 \%)\end{array}$ & $\begin{array}{l}26 \\
(7 \%)\end{array}$ & $\begin{array}{l}117 \\
(31 \%)\end{array}$ & $\begin{array}{l}223 \\
(59 \%)\end{array}$ & 464.6 & 0.000 \\
\hline 6 & $\begin{array}{l}\text { The parents of the students are } \\
\text { satisfied with the ability of EMI } \\
\text { teachers }\end{array}$ & $\begin{array}{l}34 \\
(9 \%)\end{array}$ & $\begin{array}{l}76 \\
(20 \%)\end{array}$ & $\begin{array}{l}29 \\
(8 \%)\end{array}$ & $\begin{array}{l}144 \\
(38 \%)\end{array}$ & $\begin{array}{l}97 \\
(26 \%)\end{array}$ & 118.9 & 0.000 \\
\hline 7 & $\begin{array}{l}\text { Standard benchmarks of language } \\
\text { proficiency for EMI teachers are } \\
\text { available officially }\end{array}$ & $\begin{array}{l}7 \\
(2 \%)\end{array}$ & $\begin{array}{l}7 \\
(2 \%)\end{array}$ & $\begin{array}{l}34 \\
(9 \%)\end{array}$ & $\begin{array}{l}208 \\
(55 \%)\end{array}$ & $\begin{array}{l}124 \\
(33 \%)\end{array}$ & 408.1 & 0.000 \\
\hline 8 & $\begin{array}{l}\text { The job of teachers is becoming } \\
\text { more challenging/difficult with the } \\
\text { growing trend of EMI at the primary } \\
\text { level }\end{array}$ & $\begin{array}{l}215 \\
(57 \%)\end{array}$ & $\begin{array}{l}146 \\
(38 \%)\end{array}$ & $\begin{array}{l}7 \\
(2 \%)\end{array}$ & $\begin{array}{l}7 \\
(2 \%)\end{array}$ & $\begin{array}{l}5 \\
(1 \%)\end{array}$ & 510.3 & 0.000 \\
\hline
\end{tabular}


Statistical analys is of statement No.1 testifies that the respondents significantly $\left(X^{2}=383.3\right.$ and $\mathrm{p}<0.05)$ disagreed $(\mathrm{DA}=37 \%, \mathrm{SDA}=51 \%)$ that they provided a good model of English to the students.

Analysis of statement No. 2 shows that the teachers significantly $\left(\chi^{2}=488.9\right.$ and $\left.p<0.05\right)$. disagreed $(\mathrm{DA}=37 \%, \mathrm{SDA}=57 \%)$ that they had received training for teaching through EMI.

Statistical analys is of statement No. 3 testifies that the respondents significantly $\left(\chi^{2}=546.1\right.$ and $\mathrm{p}<0.05)$ disagreed $(\mathrm{DA}=34 \%, \mathrm{SDA}=61 \%)$ that the teachers were provided enough departmental opportunities to improve their capacity for EMI.

Analysis of statement No. 4 indicates that the participants significantly $\left(X^{2}=524.3\right.$ and $p<$ $0.05)$ disagreed $(\mathrm{DA}=37 \%, \mathrm{SDA}=58 \%)$ that $\mathrm{EMI}$ was a part of pre-service and in-service training.

Statistical analysis of statement No. 5 testifies that the respondents significantly $\left(X^{2}=464.6\right.$ and $\mathrm{p}<0.05)$ disagreed $(\mathrm{DA}=31 \%, \mathrm{SDA}=59 \%)$ that the teachers could teach through EMI.

Statistical analysis of statement No. 6 testifies that the respondents significantly $\left(X^{2}=118.9\right.$ and $\mathrm{p}<0.05)$ disagreed $(\mathrm{DA}=38 \%, \mathrm{SDA}=26 \%)$ that the parents of the students were satisfied with the ability of EMI teachers.

Analysis of statement 7 reveals that the participants significantly $\left(X^{2}=408.1\right.$ and $\left.p<0.05\right)$ disagreed $(\mathrm{DA}=55 \%, \mathrm{SDA}=33 \%)$ than standard benchmarks of language profic iency for EMI teachers were available officially.

Analysis of statement 8 indicates that the respondents significantly $\left(X^{2}=510.3\right.$ and $\left.p<0.05\right)$ agreed $(\mathrm{A}=38 \%, \mathrm{SA}=57 \%)$ that the job of teachers was becoming more challenging/difficult with the growing trend of EMI at the primary level.

\section{Discussion}

This study revealed that the majority of the teachers found it difficult to provide a useful EMI classroom environment. The study also revealed that teachers found it difficult to teach the content effectively and elaborate or explain concepts in English properly. Teachers also lacked essential and requisite competencies like fluency in English, correct pronunciation, and intonation, and grammar. The root cause of these difficulties and inabilities in EMI seems to be their under-qualification at the primary level in Pakistan. The findings in the British Council report are in line with this research (Dearden, 2016). The current study also found out that English is considered an important subject by most of the respondents. These findings are also identical to the findings of English Education and Language Initiatives in the province of Punjab and the findings of the Annual Status of Education Report of 2013.

Students need a very intensive and conducive environment for learning in an EMI set. But the teachers found it very difficult to provide a linguistically rich environment to these students through EMI. The students can easily make sense of the language of instruction in the schools. Children are born with the capacity of developing new habits for learning and therefore quickly adjust themselves in the EMI environment but other factors like parental support and educational resources for sociocultural activities within and without the schools make it less effective. As far as the learning of the students is concerned, it gets less negatively affected through EMI.

Many of the primary school teachers are untrained therefore they face more problems while teaching all the subjects through the medium of the English language. They find it difficult to provide a perfect model of English to be emulated by the students. The stream of EMI is not a part of the teachers' in-service and pre-service training. There are no written guidelines available for the teachers regarding EMI teaching. Primary school teachers are not provided enough departmental opportunities for their capacity building in EMI. To qualify as an EMI teacher no official standard of language proficiency is available. The parents of the students are not satisfied with the status of teaching and ability of the teachers at the primary level. The trend towards EMI at the primary level is increasing making the job of these teachers more difficult. These problems need further research-based exploration as suggested by Macaro (2018).

\section{Conclusions}

According to Macaro (2018), the demand for English medium instruction is increasing globally and the public is ever more interested in its introduction at the primary level. This demand is also increasing in Pakistan. Many people are skeptical about the premise that the language proficiency of the students gets automatically improved through EMI. It is a fact that only the medium of instruction is not responsible for effective teaching and learning. The other factors including quality of textbooks, 
school environment, and teachers play a vital role and affect the students' learning at the primary level (Naik, 2011). The present study was an attempt in finding out the problems teachers and students face in EMI setting at the primary school level in Pakistan. The most important factor affecting the students' learning seems to be the lack of teachers' competencies to teach effectively using EMI. As explored in this study the primary school teachers lacked proficiency and skills for using EMI.

The students do not face substantial issues when taught through the medium of the English language. The learning of the students gets affected negatively in EMI settings mainly because of the lack of educational resources and scarcity of competent teachers. This is because the entry-level qualification to teach at the primary level is very low as is evident from the test conducted by the British Council for primary school teachers in the province of Punjab (Dearden, 2016).

\section{Recommendations}

All the primary school teachers may be trained for the provision of an EMI environment to the students at the primary level. The skills of testing and evaluation through EMI may also be included in the teacher training. Through pre-service and in-service training, the English language proficiency of the teachers may be improved. Instead of conventional academic and professional education, the new EMI-related qualification for teachers at the primary level may be introduced. For the effective implementation of EMI at the primary level the teachers may be trained in all four skills of the English language, especially in the speaking skill.

The teachers at the primary level may be guided through written guidelines specifying how to teach through EMI. Pre-service and in-service training may be provided for English medium education. The entry-level qualification may be enhanced for inducting competent teachers for EMI. The academic qualification of these teachers may be improved and capacity-building workshops and training may be arranged for EMI teachers. For setting a new recruitment criterion of new teachers the benchmark for language proficiency may be officially provided.

\section{References}

Bari, F. (2014). English at a cost. Retrieved from://www.dawn.com/news/1080892/english-at-a-cost

Buneri, N. (2014). Introducing uniform edu system in KP a feather in PTI's cap. Retrieved from http://www.nation.com.pk/nationa1/13-Mar-2014/introducing-unif orm-edu-system-in-kp-afeather-in-pti-s-cap

Coleman, H. (2010). Teaching and learning in Pakistan: The role of language in education. Islamabad: British Council.

Dearden, J. (2016). English as a medium of instruction-a growing global phenomenon: Phase 1. London: British Council.

Government of Pakistan (2009). National Education Policy. Ministry of Education, Islamabad.

Gravetter, F.J., \& Forzana, L.A.B (2009). Research methods for behavioral sciences. United States: Wordsworth.

Keuk, C., \& Tith, M. (2013). The enactment of English-medium instruction (EMI) undergraduate program in Cambodia: Students' voices. International Journal of Innovation in English Teaching and Research, 2(2), 159-175.

Kim, J. (2011). Relationships among motivation, contextual factors, and achievement in on-offline blended English writing class. English Language \& Literature Teaching, 17(4), 97-122.

Lei, J., \& Hu, G. (2014). Is English-medium instruction effective in improving Chinese undergraduate students' English competence? International Review of Applied Linguistics in Language Teaching, 52(2), 99-126. http://dx.doi.org/10.1515/iral-2014-0005

Macaro, E. (2018). English Medium Instruction: Time to start asking some difficult questions. Retrieved from https://www.modernenglishteacher.com/

Manan, S. M. D. \& Dumanig, F. P. (2015). The disjunction between language policy and children's socio-cultural ecology - an analysis of English- medium education policy in Pakistan. Language and Education, 29(5), 453-473.DOI: 10.1080/09500782.2015.1046882.

Mansoor, S. (2004). The medium of instruction dilemma: Implications for language planning in higher education. In S. Mansoor, S. Meraj, \& A. Tahir (Eds.), Language policy, planning, \& practice: A South Asian perspective. Karachi: Agha Khan University.

Mustafa, Z. (2013). Parents' choices of language as the medium of instruction in schools. ASER. Retrieved from http://aserpakistan.org/document/aser/2012/reports/national/Nationa12012.pdf 
Mustafa, Z. (2020). Which language? Retrieved from http://www.zubeidamustafa.com/whichlanguage-2\#more-5923

Mustafa, Z. (2011). Tyranny of language in education, the problems, and its solutions. Karachi: Ushba Publishing International.

Ponto J. (2015). Understanding and Evaluating Survey Research. Journal of the advanced practitioner in oncology, 6(2), 168-171.

Rahman, T. (1996). Language and politics in Pakistan. Karachi: Oxford University Press.

Rashid, A., Muzaffar, I., Butt, S., Awan, A. A., \& Bashiruddin, A. (2013). Policy \& Practice: Teaching and Learning English in Punjab Schools. Lahore: Society for Advancement of Education (SAHE).

Rassool, N., \& Mansoor. S. (2007). Contemporary issues in language, education, and development in Pakistan. In N. Rassool (Ed.), Global issues in language, education, and development: Perspectives from postcolonial countries. (pp. 218-244). Clevedon: Multilingual Matters.

Saeed, A., Iqbal, T., \& Azam, R. (2012). Perceptions of Teachers regarding English - Medium Instructions at Secondary education in Punjab Province of Pakistan. Secondary Education Journal, 1(1): 41-53.

Shamim, F. (2008). Trends, issues, and challenges in English language education in Pakistan. Asia Pacific Journal of Education 28(3), 235-249.

Singleton, R. A. \& Straits, B. C. (2009) Approaches to social research. New York: Oxford University Press

Wolff, E. (2006). Background and history - language and language-in-education policies in Africa: problems and prospects. Oxford University Press. 